\title{
A K+F STÚDIÓ ÁLTAL MÜKÖDTETETT INNOVÁCIÓS STÚDIUM (HELYZETKÉP)
}

Szerző:

Mező Ferenc (PhD)

$\mathrm{K}+\mathrm{F}$ Stúdió Kft.

Mező Katalin (PhD)

$\mathrm{K}+\mathrm{F}$ Stúdió Kft.

Elsőszerző e-mail címe:

ferenc.mezo1@gmail.com

\section{Lektorok:}

Kelemen Lajos (PhD)

Poliforma Kft.

Hanák Zsuzsanna (PhD)

Eszterházy Károly Egyetem

...és további két anonim lektor

\begin{abstract}
Absztrakt
Az „Innovációs Studium” a K + F Stúdió Kft. egyik tehetségfejlesztő programja. Ennek a programnak a célja a fiatal (14-25 éves) kutatók fejlesztése az innováció területén.
\end{abstract}

Kulcsfogalmak: tehetség, innováció

Diszciplinák: pedagógia, pszichológia

\begin{abstract}
INNOV ATIONAL STUDIUM BY K+F STÚDIÓ KFT. (SITUATION REPORT)

The 'Innovational Studium' is one of the talent development program of the Hungarian $\mathrm{K}+\mathrm{F}$ Stúdió Kft. The aim of this program is to develop the young (14-25 years old) researchers in the area of innovation.
\end{abstract}

Keywords: talent, innovation

Disciplines: pedagogy, psychology

Mező Ferenc és Mező Katalin (2020): A K+F Stúdió által működtetett Innovációs Stúdium (helyzetkép). OxIPO - interdiszciplináris tudományos folyóirat, 2020/1, 89-94. doi: 10.35405/OXIPO.2020.1.89 
„Innovációs stúdium” néven valósít meg tehetséggondozó projektet a $\mathrm{K}+\mathrm{F}$ Stúdió Kft. a 2019/2020. évben, a Nemzeti Tehetség Program támogatásával.

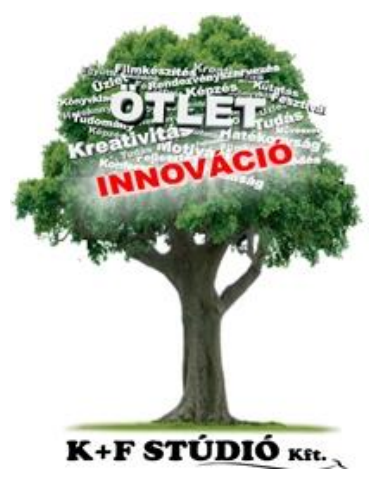

Az alábbiakban e projektben végzett tevékenységek bemutatására kerül sor.

\section{Helyzetkép a programról}

A stúdium főprogramjaként a beválogatásra került fiatal kutatók az innovációval kapcsolatos gazdagító programban vesznek részt (programvezető: dr. Mező Ferenc és dr. Mező Katalin). Ehhez a programhoz kiegészítő programelemek kapcsolódnak. Ezek:

„Innovatio” tréning. A külföldi szakértők, dr. Ildkó Psenáková és Peter Psenák bevonásával megvalósuló tréning főbb témakörei: 1. Lokális VS. globális szemlélet; 2. Nemzeti VS. nemzetközi innováció; 3. Profit- VS. nonprofit orientált szemlélet.

Innovációs és -vállalkozásfejlesztō tréning. E tréning vezetésére Mászlai Tamást kértük fel. A tréning célja: egyrészt a fiatal innovátorok vállalkozási lehetőségeiről (vállalkozások, cégek alapításának ügyrendi, pénzügyi vonatkozásairól); másrészt az innováció vállalkozások életében játszott szerepéről szóló praktikus ismeretek, tapasztalatok résztvevő központú átadása a megjelentek számára.

„Te is lehetsz innovátor!" vándorkiállitás. $\mathrm{Az}$ öt állomáson megvalósuló vándorkiállításon tableten futó interaktív tartalmak, filmek, valamint $60 \times 90$ centiméter felületű bekeretezett poszterek igyekeznek felkelteni az érdeklődést az innovációs tevékenység iránt. Megjegyzés: a 2020. első negyedévében kialakult járványhelyzet miatt az első negyedévre tervezett kiállítások a második negyedévre tolódnak, illetve akár a második félévre is csúszhatnak. Ugyanakkor a kiállítás virtuális múzeum formájában történő kidolgozása is elkezdődött.

Kiadvány. A résztvevők tanulmányait (is) tartalmazó elektronikus kötet megjelenése folyamatban van.

Tanulmányok. A program keretében megjelent, azt népszerűsítő tanulmányok egyike Mező (2019) műhelybemutató tanulmánya, ami a Különleges Bánásmód folyóiratban jelent meg. A projekt megvalósításának kezdetén készült írás bemutatta a tervezett fô- és kiegészítő programokat, a várható produktumokat.

A Magyar Tehetséggondozó Társaság (www.mateh.hu) „Tehetség” című folyóiratában jelent meg Mező és Mező (2020a) tanulmánya, mely ajánlásokat 
fogalmazott meg az innovációra neveléssel kapcsolatban. A tanulmány kitért a képességekre vonatkozó, a módszertani és ismeretbeli fejlesztésre, illetve az innovatív viselkedés motivációs jellemzői re. A múben bemutatásra került az intézményes nevelés különböző szintjeihez kapcsolódóan az innovációra nevelés sémája, főbb fókuszpontjai is (1. ábra) az óvodától a felnőttkézésig terjedően.

1. ábra: a fejlesztés lehetséges fókuszai az intézményes nevelés fázisai szerint az innovációra nevelés aspektusából (forrás: a Szerzók)

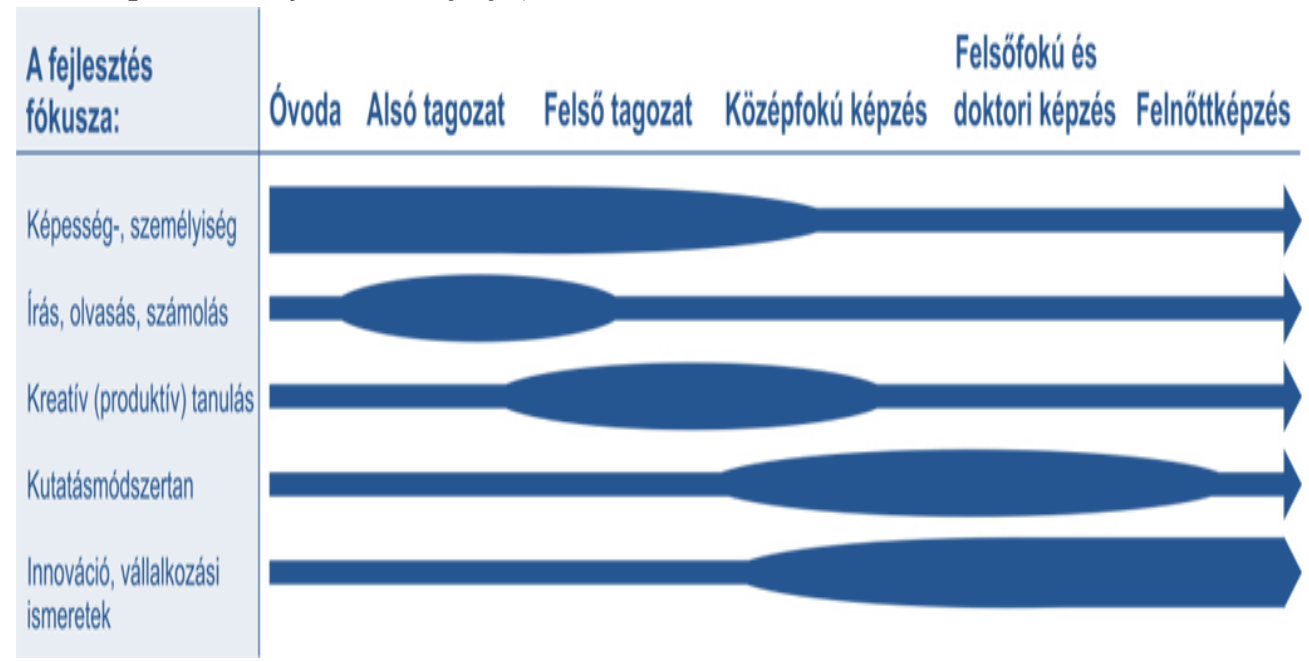

Megjegyzés: a vonalak folytonossága jelzi, hogy az adott fejlesztési területek élethossziglan lényegesek lehetnek. A vonalak vastagodása jelzi, hogy az adott fejlesztési területre az intézményi nevelés mely fázisában célszerü kitüntetett figyelmet fordítani az innovációra nevelés aspektusából.

\section{Konferenciák, előadások}

Az „Innovációs Stúdium” projekt keretében ugyan nem volt önálló konferencia megszervezve, ám a résztvevőknek lehetôsége van bekapcsolódni egyéb konferenciákba. Az előadások részben a programról, részben pedig a bevont személyek kutatásairól, innovációs elképzeléseiről szóltak - de mindenképen volt disszeminációs jelentőségük is.

A járvány miatt e-konferenciák megrendezésére kerülhet sor 2020. első félévében. A program keretében megcélzott konferenciák körét (eredeti helyszínük és időpontjuk megjelöléséve) a 2. ábra foglalja össze. 
2. ábra: az „Innovációs Stúdium” keretében az alábbi e-konferenciákon vehetnek részt a beválogatott hallgatók (forrás: a Szerzőo)

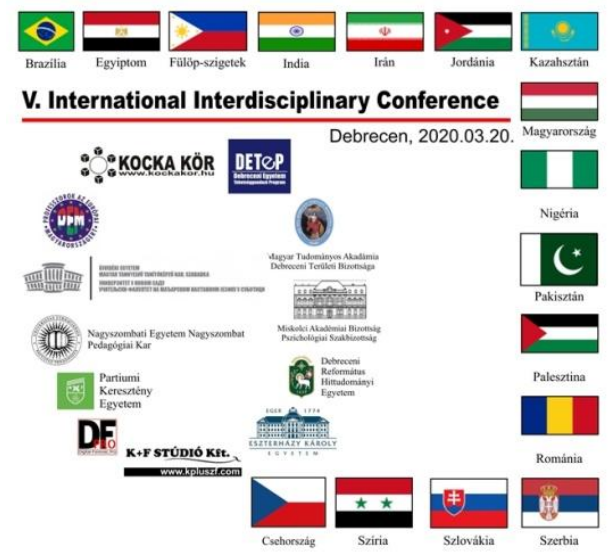

KUTATÁS ÉS INNOVÁCIÓ KONFERENCIA そ8

Prága, 2020.04.28.

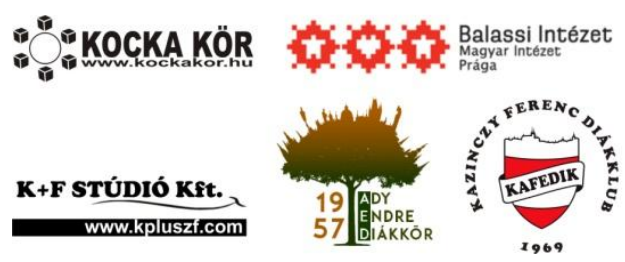

INNOVÁCIÓ HATÁROK NÉLKÜL 2020 KONFERENCIA

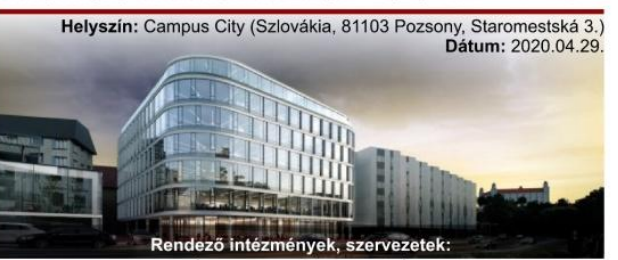

- : KOcKa KÖR $\mid$ N AYT R O K+F STúdió Kft.
E konferenciák közül jelen műhelybemutató tanulmány megjelenéséig az $\mathrm{V}$. Nemzetközi Interdiszciplináris Konferencia valósult meg, melyen a pályázat keretében a következő prezentációk kerültek bemutatásra:

Fábián Fruzsina és Varga Boglárka (2020): Tanulásban akadályozott gyermekek vizsgálata zenei területen.

Koncz Anna Hajnalka (2020): PET-CT hibrid képalkotás szerepe tüdő és fej-nyak tumorok $\mathrm{N}$ és $\mathrm{M}$ klinikai stagingjében

Koncz Anna Hajnalka és Koncz Béla Norbert (2020): Reformáció hatása a medicinára

Mező Ferenc (2020): Innovációs Stúdium

Mező Lilla Dóra (2020): „Változnak az idők": a nők helyzete Ghánában

Mező Kristóf Szíriusz (2020): A jövő autói

Roskó Tibor (2020): Mesterséges intelligencia fejlesztések három év távlatában

Szalacsi Norbert és Veres Szilvia (2020): Vízhiány stressz hatása lucerna genotípusok csírázási és vegetatív jellemzőire

Szatmári Roland (2020): Száradásos repedezés vizsgálata

Tóth Ákos (2020): A 95Ru és 95Tc izotópok felezési idejének meghatározása gamma-spektroszkópiával

Varga Boglárka és Fábián Fruzsina (2020): Tanulásban akadályozott gyermekek vizsgálata vizuális területen

Varga Imre Solt (2020): Luxemburgi Zsigmond huszita hadjáratainak első fele (1420-1422) és a hadjáratokat befolyásoló földrajzi tényezők

Külföldi tanulmányút. A program keretében Csehországba és Szlovákiába (konferencia- 
szerepléssel és határon túli fiatalokkal történő közvetlen együttmúkö-désen alapuló) tanulmányutat is terveztünk, ami a járványhelyzetre való tekintettel későbbi időpontra tolódik.

Kisfilmek. A projekt keretében két kisfilm felvételei elkészültek, jelenleg a vágás és az utómunkálatok folynak.

\section{Köszönetnyilvánítás}

Az Innovációs Stúdium megvalósítása a Nemzeti Tehetség Program támogatásával valósult meg (azonosító: NTP-PKTF-190002). A támogatást ezúton is köszönjük!

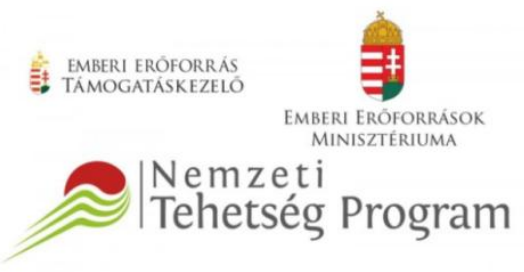

\section{Irodalom}

Mező Ferenc (2019): Innovációs Stúdium. Különleges Bánásmód, V.. évf. 2019/4, 85-87. Letöltés: 2020.03.04. Web: https://gygyk.unideb.hu/sites/default/fil es/upload_documents/kb_2019_4_innov acios_studium.pdf

Mező Ferenc és Mező Katalin (2020a): Az innovációra nevelés, mint a tehetséggondozás egy lehetséges célja. Tehetség lap (megjelenés folyamatban).

Fábián Fruzsina és Varga Boglárka (2020):Tanulásban akadályozott gyermekek vizsgálata zenei területen. In: Mező Ferenc (szerk.): V. Nemzetközi Interdiszciplináris Konferencia: brosúra. A szek- ciók és ar. elóadók listája. Letöltés: 2020.03.21. Web: https://drive. google.com/file/d/1djweOM2fqWv48w CR_HZPSdAfP_LWzyqq/view

Koncz Anna Hajnalka (2020): PET-CT hibrid képalkotás szerepe tüdő és fej-nyak tumorok $\mathrm{N}$ és $\mathrm{M}$ klinikai stagingjében. In: Mező Ferenc (szerk.): V. Nemzetközi Interdiszciplináris Konferencia: brosúra. A szekeciók és az elöadók listája. Letöltés: 2020.03.21. Web: https://drive.google. com/file/d/1djweOM2fqWv48wCR_HZ PSdAfP_LWzyqq/view

Koncz Anna Hajnalka és Koncz Béla Norbert (2020): Reformáció hatása a medicinára. In: In: Mező Ferenc (szerk.): $V$. Nemzetközi Interdiszciplináris Konferencia: brosúra. A szekeciók és az elöadók listája. Letöltés: 2020.03.21. Web: https://drive. google.com/file/d/1djweOM2fqWv48w CR_HZPSdAfP_LWzyqq/view

Mező Ferenc (2020): Innovációs Stúdium. In: Mező Ferenc (szerk.): V. Nemzetköz̨i Interdiszciplináris Konferencia: brosúra. A szekeciók és az elöadók listája. Letöltés: 2020.03.21. Web: https://drive.google. com/file/d/1djweOM2fqWv48wCR_HZ PSdAfP_LWzyqq/view

Mező Lilla Dóra (2020): „Változnak az idők": a nők helyzete Ghánában. In: Mező Ferenc (szerk.): V. Nemzetközi Interdiszciplináris Konferencia: brosúra. A szekciók és az elöadók listája. Letöltés: 2020.03.21. Web: https://drive.google. com/file/d/1djweOM2fqWv48wCR_HZ PSdAfP_LWzyqq/view

Mező Kristóf Szíriusz (2020): A jövő autói. In: Mező Ferenc (szerk.): V. Nemzetközi 
Interdiszciplináris Konferencia: brosúra. A sqekciók és az elöadók listája. Letöltés: 2020.03.21. Web: https://drive.google. com/file/d/1djweOM2fqWv48wCR_HZ PSdAfP_LWzyqq/view

Roskó Tibor (2020): Mesterséges intelligencia fejlesztések három év távlatában. In: Mező Ferenc (szerk.): V. Nemzetkëzi Interdiszciplináris Konferencia: brosúra. A szekciók és az elöadók listája. Letöltés: 2020.03.21. Web: https://drive.google. com/file/d/1djweOM2fqWv48wCR_HZ PSdAfP_LWzyqq/view

Szalacsi Norbert és Veres Szilvia (2020): Vízhiány stressz hatása lucerna genotípusok csírázási és vegetatív jellemzőire. In: Mező Ferenc (szerk.): V. Nemzetkǫ̈̈i Interdiszciplináris Konferencia: brosúra. A szekciók és az elöadók listája. Letöltés: 2020.03.21. Web: https://drive.google. com/file/d/1djweOM2fqWv48wCR_HZ PSdAfP_LWzyqq/view

Szatmári Roland (2020): Száradásos repedezés vizsgálata. In: Mező Ferenc (szerk.): $V$. Nemzetközi Interdiszciplináris Konferencia: brosúra. A szekciók és az elöadók listája. Letöltés: 2020.03.21. Web: https://drive. google.com/file/d/1djweOM2fqWv48w CR_HZPSdAfP_LWzyqq/view
Tóth Ákos (2020): A 95Ru és 95Tc izotópok felezési idejének meghatározása gamma-spektroszkópiával. In: Mező Ferenc (szerk.): V. Nemzetközi Interdiszciplináris Konferencia: brosúra. A sqekeciók és az elöadók listája. Letöltés: 2020.03.21. Web: https://drive.google.com/file/d/1djwe OM2fqWv48wCR_HZPSdAfP_LWzyqq /view

Varga Boglárka és Fábián Fruzsina (2020): Tanulásban akadályozott gyermekek vizsgálata vizuális területen. In: Mező Ferenc (szerk.): V. Nemzetközi Interdiszciplináris Konferencia: brosúra. A szekciók és az elöadók listája. Letöltés: 2020.03.21. Web: https://drive.google.com/file/d/ 1djweOM2fqWv48wCR_HZPSdAfP_L Wzyqq/view

Varga Imre Solt (2020): Luxemburgi Zsigmond huszita hadjáratainak első fele (1420-1422) és a hadjáratokat befolyásoló földrajzi tényezők. In: Mező Ferenc (szerk.): V. Nemzetközi Interdiszciplináris Konferencia: brosura. A szekciók és az elöadók listája. Letöltés: 2020.03.21. Web: https://drive. google.com/file/d/1djweOM2fqWv48w CR_HZPSdAfP_LWzyqq/view 